\title{
Lithium Distribution Across the Membrane of Motoneurons in the Isolated Frog Spinal Cord
}

\author{
P. Grafe, J. Rimpel, M. M. Reddy, and G. ten Bruggencate \\ Physiologisches Institut der Universität München, Pettenkoferstrasse 12, D-8000 München 2, Federal Republic of Germany
}

\begin{abstract}
Lithium sensitive microelectrodes were used to investigate the transmembrane distribution of lithium ions $\left(\mathrm{Li}^{+}\right)$in motoneurons of the isolated frog spinal cord. After addition of $5 \mathrm{mmol} \cdot \mathrm{1}^{-1} \mathrm{LiCl}$ to the bathing solution the extracellular diffusion of $\mathrm{Li}^{+}$was measured. At a depth of $500 \mu \mathrm{m}$, about $60 \mathrm{~min}$ elapsed before the extracellular $\mathrm{Li}^{+}$ concentration approached that of the bathing solution. Intracellular measurements revealed that $\mathrm{Li}^{+}$started to enter the cells soon after reaching the motoneuron pool and after up to $120 \mathrm{~min}$ superfusion, an intra - to extracellular concentration ratio of about 0.7 was obtained. The resting membrane potential and height of antidromically evoked action potentials were not altered by $5 \mathrm{mmol} \cdot 1^{-1} \mathrm{Li}^{+}$.
\end{abstract}

Key words: Lithium - Ion sensitive microelectrode Intracellular lithium - Motoneurons - Spinal cord - Frog

\section{Introduction}

The mechanism of the therapeutic action of lithium $\left(\mathrm{Li}^{+}\right)$is still unclear. One factor involved may be an influence upon other ions which are important for neuronal functions. In this context several investigations have shown that $\mathrm{Li}^{+}$can interfer with the active and electrogenic transport of $\mathrm{Na}^{+}$and $\mathrm{K}^{+}$-ions observable after neuronal stimulation in rabbit or rat vagus nerve (Ritchie and Straub 1957; Ploeger 1974; Smith 1979), amphibian optic nerve (Tang et al. 1980), rat sympathetic ganglion (ten Bruggencate et al. 1981), frog spinal cord (Davidoff and Hackman 1980; Grafe et al. 1981) and rat cerebellum (Ullrich et al. 1980). The interpretation of these experiments, however, remained limited with respect to the concentration of $\mathrm{Li}^{+}$in the nervous tissue as a function of the application time and to the unknown extra-/intracellular distribution ratio of $\mathrm{Li}^{+}$. The development of a lithium sensitive ion exchanger suitable for microelectrodes (Güggi et al. 1975) now offers the possibility for obtaining these data. Thomas et al. (1975) have applied lithium ion sensitive microelectrodes $\left(\mathrm{Li}^{+}\right.$-ISMEs) to determine $\mathrm{Li}^{+}$accumulation in snail neurons. We have extended this to vertebrate neurons and used $\mathrm{Li}^{+}$-ISMEs to investigate the distribution of $\mathrm{Li}^{+}$ across the membrane of motoneurons in the isolated frog spinal cord. The aims of this project were (a) to observe the kinetics of extracellular and intracellular $\mathrm{Li}^{+}$in an isolated preparation after application of the ion into the superfusion fluid. (b) To determine the time required to reach a steady state concentration of $\mathrm{Li}^{+}$inside the cell.'(c) To measure the steady state intra-/extracellular concentration ratio.

Send offprint requests to $\mathrm{P}$. Grafe at the above address

\section{Methods}

Experiments were performed on the frog, Rana esculenta, using the approach described in detail by Sonnhof et al. (1975). Briefly, after decapitation a ventral laminectomy was performed in cooled Ringer solution. The spinal cord, including dorsal and ventral roots of the lumbar segments, was removed and placed in a recording chamber (volume $1.5 \mathrm{ml}$ ), which was continuously superfused with Ringer solution by means of a roller pump $(2.5 \mathrm{ml} / \mathrm{min})$. The Ringer solution contained $\left(\mathrm{mmol} \cdot 1^{-1}\right)$ : $\mathrm{NaCl} 98.0, \mathrm{KCl} 3.6, \mathrm{CaCl}_{2}$ $2.0, \mathrm{NaHCO}_{3} 12.0$, glucose 10.0. The pH was continuously monitored and adjusted to $7.3-7.5$ by means of a variable mixture of $\mathrm{O}_{2}$ and $\mathrm{CO}_{2}$. The temperature of the perfusion fluid was adjusted to $21^{\circ} \mathrm{C}$. The dorsal roots of the lumbar segments of one side were placed on silver wire electrodes for stimulation and covered with vaseline; the ventral roots of the same side were drawn into glass suction electrodes which permitted stimulation or recording from the ventral roots. In order to facilitate the insertion of microelectrodes, a large area of the meninges including the pia was carefully removed between ventral and dorsal roots. Electrode tracks aiming at motoneurones were guided by antidromic field potentials; motoneurones were identified by antidromic invasion from the stimulated ventral roots.

Ion sensitive microelectrodes (ISMEs) with outer tip diameters of approximately $0.5-1 \mu \mathrm{m}$ were drawn from borosilicate theta-capillaries. Whilst applying pressure $\left(\mathrm{N}_{2}\right)$ to one channel, a drop of hexamethyl-disilazane (Sigma, München, FRG) was backfilled into the other channel. The electrode was then inserted into a horizontal heating coil (approximately $400^{\circ} \mathrm{C}$ ) and after baking for $20 \mathrm{~min}$, a drop of lithium sensitive ion exchange resin (Güggi et al. 1975) was injected into the silanized tip under microscopic control. This channel was then back-filled with $150 \mathrm{mmol} \cdot 1^{-1} \mathrm{LiCl}$. The reference barrel was filled with $4 \mathrm{~mol} \cdot 1^{-1}$ potassium acetate for conventional recording of potentials. After insertion of $\mathrm{Ag} / \mathrm{AgCl}$ wires, the electrodes were sealed with wax. The resistance of the ion sensitive barrel was about $10^{11} \Omega$, while that of the reference barrel ranged between $10^{7}$ and $5 \cdot 10^{7} \Omega$ (measured with dc-current). High-impedance buffer amplifiers and differential subtraction amplifiers were used to obtain the pure ion signal and the potential of the reference barrel. Both potentials were recorded on a chart recorder that filtered out high frequency components (above $10 \mathrm{~Hz}$ ). Fast field potentials, synaptic and action potentials were recorded with the reference barrel and displayed on an oscilloscope. The amplitude of the antidromic spike was also monitored by the chart recorder using a peak height detector (Courtice 1977). 
Usually, the calibrations for intracellular measurements were carried out using standard solutions of different $\mathrm{LiCl}$ concentrations $\left(1,3\right.$ and $\left.5 \mathrm{mmol} \cdot \mathrm{1}^{-1}\right)$ against a constant background of $100 \mathrm{mmol} \cdot 1^{-1} \mathrm{KCl}$ plus $16 \mathrm{mmol} \cdot 1^{-1} \mathrm{NaCl}$ or less (see below). The same standard $\mathrm{Li}^{+}$concentrations in Ringer solution were used to obtain values for extracellular measurements (see Fig. 2B). This method avoided calculations using selectivity coefficients to be determined for each electrode (Thomas et al. 1975). The actual concentrations of $\mathrm{Na}^{+}$in the intracellular calibration solutions were chosen by adjusting the voltage change between Ringer solution and various intracellular calibration solutions to the potential jump of the difference signal $\left(\mathrm{Li}_{i}\right)$ after withdrawal from the intracellular compartment (cf. Fig. 5).

$\mathrm{Li}_{i}$ was calculated as a concentration, since the Ringer solution and the intracellular calibration solution had about the same ionic strength, Also the activity coefficient for $\mathrm{Li}^{+}$is probably the same inside the cell as outside (for discussion see Thomas 1978). Some electrodes were tested for their selectivity coefficients against $\mathrm{Na}^{+}$and $\mathrm{Ca}^{2+}$. Using a computer program based on the Nikolsky equation and calibration solutions containing a constant background concentration of $\mathrm{Na}^{+}$and different concentrations of $\mathrm{Li}^{+}$, a selectivity coefficient against $\mathrm{Na}^{+}$of $0.046 \pm 0.014$ (mean $\pm \mathrm{SD} ; n=20$ ) was obtained. A similar program, using different concentrations of $\mathrm{Ca}^{2+}$ in solutions with constant amounts of $\mathrm{Na}^{+}$and $\mathrm{Li}^{+}$was used to determine the selectivity coefficient against $\mathrm{Ca}^{2+}(0.18 \pm 0.08 ; n=11)$. The $\mathrm{Mg}^{2+}$ interference of the $\mathrm{Li}^{+}$ion exchanger resin was not tested; according to the literature it is unlikely to be important $\left(\mathrm{Li}^{+}: \mathrm{Mg}^{2+}\right.$ $=1: 0.003$; Güggi et ai. 1975).

The pure ion potential of extracellularly placed Li-ISMEs in the absence of $\mathrm{Li}^{+}$had a certain value because of the presence of interferring ions in the extracellular space. Upon application of $\mathrm{Li}^{+}$, this potential $\left(\mathrm{Li}_{e}\right.$ ) changed according to the changing extracellular $\mathrm{Li}^{+}$concentration. Intracellularly, a similar ion potential was observed in the absence of $\mathrm{Li}^{+}$; ("apparent" $\mathrm{Li}_{\mathrm{i}}=E_{\mathrm{Li}}-E_{m} ; E_{\mathrm{Li}}=$ voltage of ion barrel, $E_{m}$ = voltage of reference barrel). This "apparent" $\mathrm{Li}_{i}$ is set by the intracellular activities of interferring ions, and may change even in absence of $\mathrm{Li}^{+}$(see Fig. 2). In particular, an alteration of the $\mathrm{Na}^{+}$activity is the most important factor.

\section{Results}

\section{Extracellular $\mathrm{Li}^{+}$Distribution}

Experiments were performed with extracellularly placed LiISMEs in order to quantify the entry of $\mathrm{Li}^{+}$into the spinal cord as a function of time. Figure 1 illustrates changes of $\mathrm{Li}_{e}$ at a depth of $500 \mu \mathrm{m}$ below the lateral surface of the cord (location of the motoneuron pool); the time course of $\mathrm{Li}^{+}$ changes in the bathing chamber is shown to the left. Although a constant $\mathrm{Li}^{+}$level in the bath was reached within $2 \mathrm{~min}$, it took about $60 \mathrm{~min}$ until $\mathrm{Li}_{e}$ within the motoneuron pool approached the applied concentration of $5 \mathrm{mmol} \cdot 1^{-1}$. Even after such a long $\mathrm{Li}^{+}$application, $\mathrm{Li}_{e}$ was still about $0.5 \mathrm{mmol} \cdot 1^{-1}$ less than the bath concentration. Observations from 5 different spinal cord preparations have shown that a latency of $1-2 \mathrm{~min}$ passed between the time of $\mathrm{Li}^{+}$entrance at the surface and a measurable $\mathrm{Li}^{+}$signal at a depth of $400-$ $500 \mu \mathrm{m} ; \mathrm{Li}_{e}$ then increased to $3.58 \pm 0.34 \mathrm{mmol} \cdot 1^{-1}$ (mean $\pm \mathrm{SD} ; n=5$ ) after $30 \mathrm{~min}$ and to $4.33 \pm 0.47 \mathrm{mmol} \cdot 1^{-1}$ $(n=3)$ after $60 \mathrm{~min}$ of application.



Fig. 1. Extracellular $\mathrm{Li}^{+}$transients in the isolated frog spinal cord. Changes in bath and tissue $\mathrm{Li}^{+}$concentration induced by steplike addition of $5 \mathrm{mmol} \cdot 1^{-1} \mathrm{LiCl}$ to the superfusate (time indicated by bars; corrected for the delay caused by the tube system). The electrode position in the tissue was $500 \mu \mathrm{m}$ below the lateral surface of the spinal cord within the motoneuron pool

\section{$\mathrm{Li}^{+}$Distribution across the Motoneuron Membrane}

Before describing intracellular $\mathrm{Li}^{+}$measurements, it is necessary to report some of our general observations with the $\mathrm{Li}^{+}$-ISME in the intracellular fluid. Due to the sensitivity of the ion exchanger to $\mathrm{Na}^{+}$and $\mathrm{Ca}^{2+}$, and the existing concentration gradients for those ions, a voltage jump of the difference signal ("apparent" $\mathrm{Li}_{i}$ ) of up to $50 \mathrm{mV}$ could be observed upon impalement of a cell. Additionally, changes in the membrane potential $\left(E_{m}\right)$ and the height of the antidromically evoked action potentials (a. AP) were accompanied by voltage shifts of "apparent" $\mathrm{Li}_{i}$. Such effects were frequently seen in the period following the impalement; one typical example is illustrated in Fig. $2 \mathrm{~A}$. At the beginning of the recording ( $1 \mathrm{~min}$ after impalement) $E_{m}$ was $-63 \mathrm{mV}$ and the a. AP was $75 \mathrm{mV}, E_{m}$ then slowly rose to $-73 \mathrm{mV}$ and simultaneously the height of the a. AP increased first to $86 \mathrm{mV}$ and was then blocked. In this situation, the antidromic stimulation induced a ventral root EPSP (Sonnhof et al. 1977). An a. AP of $92 \mathrm{mV}$ could only be elicited when superimposed on a spontaneous synaptic depolarization. Parallel to the increase in resting membrane potential and a. AP amplitude, a voltage shift of the $\mathrm{Li}^{+}$-ISME of $15 \mathrm{mV}$ occurred, probably due to the outward pumping of $\mathrm{Na}^{+}$ during the "sealing in" of the electrode. Opposite, but similar changes in the $\mathrm{Li}_{i}$-voltage were observed when the membrane depolarized as a result of cell deterioration. Therefore, we restricted our analysis of intracellular $\mathrm{Li}^{+}$concentrations to neurons, which had stable $E_{m}$ and a. AP. Maximally, a change of $5 \mathrm{mV}$ in the $E_{m}$ and $10 \mathrm{mV}$ in the a. AP was tolerated (16 motoneurons from 15 spinal cord preparations).

Figure 3 illustrates a typical experiment showing the transmembrane $\mathrm{Li}^{+}$movement into a motoneuron. After the impalement of the cell, we measured the intracellular $\mathrm{Li}^{+}$ accumulation after application of $5 \mathrm{mmol} \cdot 1^{-1} \mathrm{Li}^{+}$into the bathing solution (Fig. $3 \mathrm{C}$ ). After about $2 \mathrm{~min}$ (range $2-$ $5 \mathrm{~min}) \mathrm{Li}^{+}$entered the motoneuron, whilst $E_{m}$ (Fig. 3D) and the height of the a. AP (Fig. 3E) remained unchanged. Thirty minutes later the impalement became unstable and the electrode was withdrawn from the cell (not illustrated). This same electrode was then positioned extracellularly close to the recorded neuron and, after a washing period of about $1 \mathrm{~h}, \mathrm{Li}^{+}$ was reapplied. The kinetics of the extracellular $\mathrm{Li}^{+}$diffusion was then recorded (Fig. 3B). 
A


B

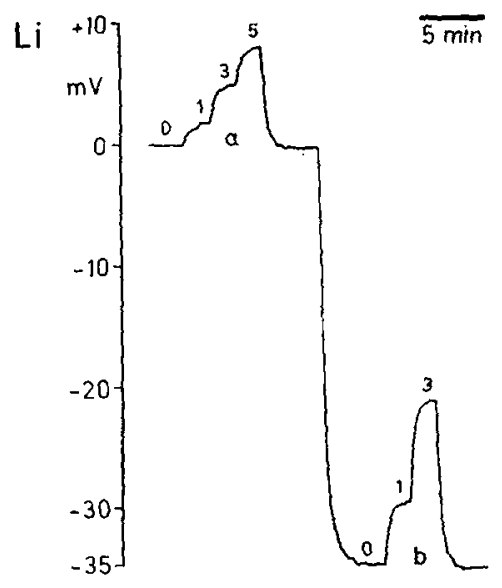

Fig. $2 \mathrm{~A}$ and B. Intracellular performance and calibration of $\mathcal{L} i^{+}$-ISME. (A) Changes in the ion signal (Lij), resting membrane potential $\left(E_{m}\right)$, and antidromic spike (a.AP) during the period following impalement of a motoneuron. Simultaneous to the increase in $E_{m}$ and the a. AP amplitude, a voltage shift of "apparent" $\mathrm{L}_{i}$ occurred. (The asterisk after $\mathrm{Li}_{i}$ points to the fact that no $\mathrm{Li}^{+}$is present.) This is probably caused by a decrease in the intracellular $\mathrm{Na}^{+}$concentration since recordings with $\mathrm{Na}^{+}$-ISMEs showed the same behaviour (unpubiished). The ventral roots were stimulated every $10 \mathrm{~s}$; towards the end of the trace the a. AP did not invade the soma of the motoneuron. Figures above the a. AP record give the actual size of the a. AP $(\mathrm{mV})$ as read from the oscilloscope. The upward deflections on the $E_{m}$-trace are spontaneousiy occurring synaptic potentials; a. APs are not visible due to the slow frequency response of the pen recorder. (B) Voltage response of a representative $\mathrm{Li}^{+}$-ISME with different concentrations of $\mathrm{Li}^{+}(0,1,3$ and $5 \mathrm{mmol} \cdot \mathrm{1}^{-1}$ ) added to the normal Ringer solution $(a)$ and to an "intracellular calibration solution" containing $100 \mathrm{mmol} \cdot 1^{-1} \mathrm{KCl}$ and $16 \mathrm{mmol} \cdot 1^{-1}$ $\mathrm{NaCl}(b)$. Due to the sensitivity of the ion exchanger to $\mathrm{Na}^{+}$and $\mathrm{Ca}^{2+}$, a voliage jump of $35 \mathrm{mV}$ occurred upon changing from solution $a$ to $b$. Also, the electrode was more sensitive to $\mathrm{Li}^{+}$-ions in the low $\mathrm{Na}^{+}$- and low $\mathrm{Ca}^{2+}$-background solution $b$

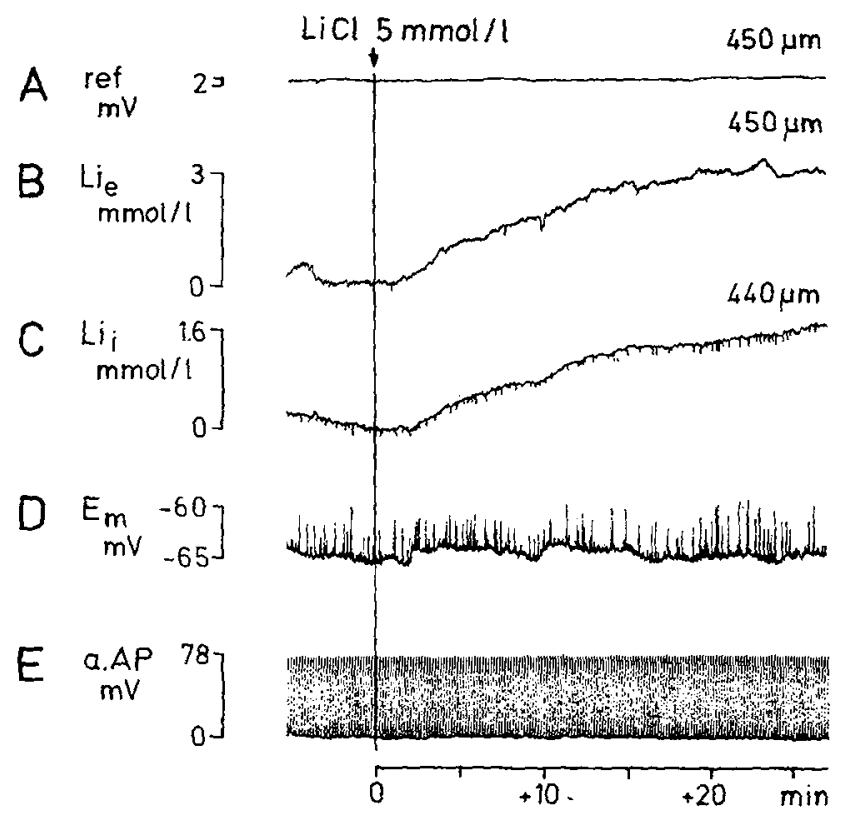

Fig. 3A-E. Li ${ }^{+}$entry into a motoneuron. Traces $(\mathbf{A})$ and $(\mathbf{B})$ illustrate the reference signal $(r e f)$ and the difference signal $\left(\mathrm{Li}_{e}\right)$ of a $\mathrm{Li}^{+}$-ISME positioned extracellularly at a depth of $450 \mu \mathrm{m}$ below the lateral surface of the spinal cord. The following 2 traces $(\mathbf{C}, \mathbf{D})$ are the corresponding signals obtained with the same electrode inside a motoneuron (depth $440 \mu \mathrm{m})$. The upward deflections on the $E_{m}$-trace are spontaneously occurring synaptic potentials. A record of the amplitude of antidromic action potentials ( $a . A P$ ), as elicited by stimulation of the ventral roots $(0.1 \mathrm{~Hz})$ is shown in $\mathbf{E}$. The cell was lost $28 \mathrm{~min}$ after the start of $\mathrm{Li}^{+}$ superfusion ( $5 \mathrm{mmol} \cdot \mathrm{1}^{-1}$, exchanged for $\mathrm{NaCl}$ and indicated by arrow and vertical line)

In several other experiments we have observed $\mathrm{Li}_{i}$ after changing from $\mathrm{Li}^{+}$Ringer to normal Ringer solution. After a short application $(15-20 \mathrm{~min}), \mathrm{Li}_{i}$ still increased for several

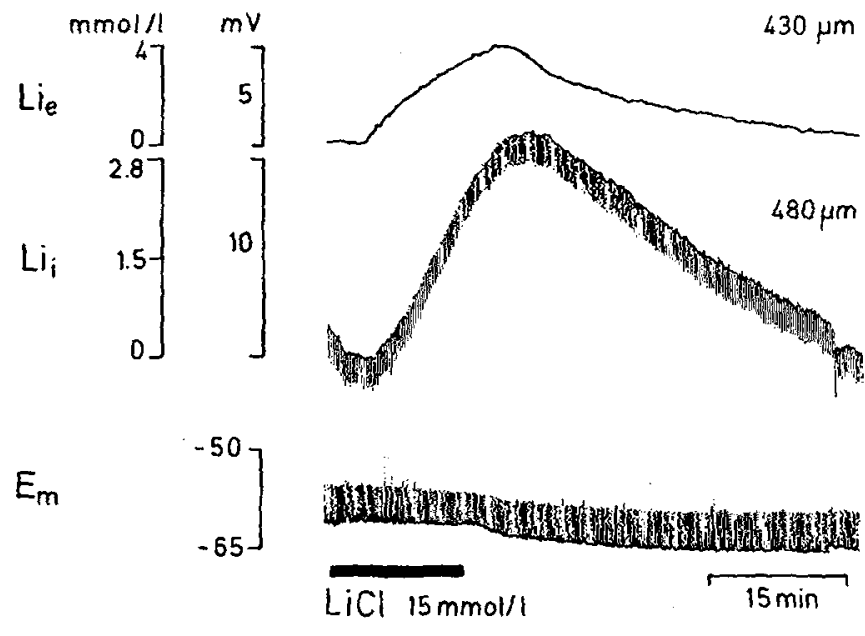

Fig. 4. Extra- and intracellular $\mathrm{Li}^{+}$transients upon brief periods of $\mathrm{Li}^{+}$ application. $\mathrm{LiCl}\left(15 \mathrm{mmol} \cdot 1^{-1}\right.$, exchanged for $\left.\mathrm{NaCl}\right)$ was applied via the bathing solution at the time indicated by the bar. In this figure, the $\mathrm{Li}_{i}$ calibration is given in both $\mathrm{mmol} \cdot \mathrm{I}^{-1}$ and $\mathrm{mV}$, thereby revealing that the sensitivity of the $\mathrm{Li}^{+}$-ion exchanger is much greater in a solution with an ionic background similar to the intracellular fluid. The registration of the membrane potential is superimposed by synaptic potentials induced by dorsal root stimulation $(0.05 \mathrm{~Hz})$. The extracellular $\mathrm{Li}^{*}$ measurement was obtained during a second $\mathrm{Li}^{+}$application after withdrawal of the electrode from the motoneuron (depth $480 \mu \mathrm{m}$ ) to a place close to the neuron (depth $430 \mu \mathrm{m}$ )

minutes despite removal of the ion from the superfusion fluid; about twice the application time was required until $\mathrm{Li}^{+}$was completely removed from the cell (see Fig. 4). In 2 other preparations we impaled motoneurons after $\mathrm{Li}^{+}$had been applied for up to $5 \mathrm{~h}$. In these cases, after changing back to normal Ringer $3-5$ min elapsed before $\mathrm{Li}_{i}$ started to fall and reached the zero level about $120 \mathrm{~min}$ later. 


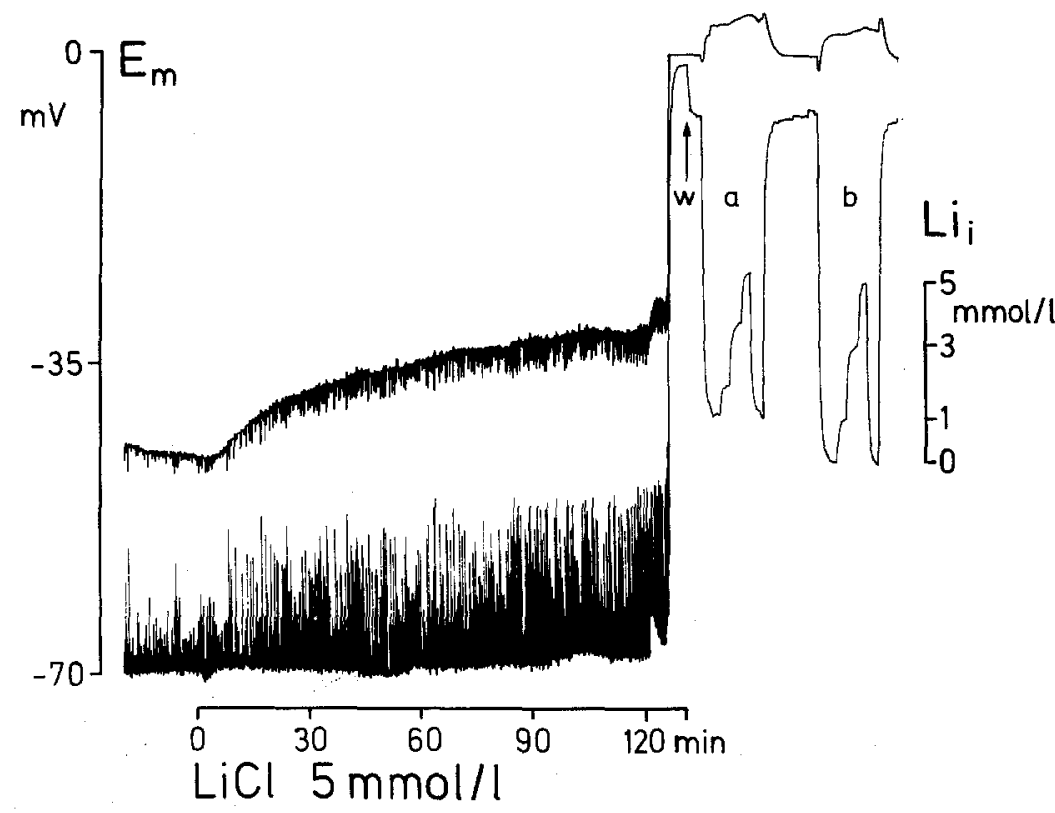

Fig.5

Steady state distribution of $\mathrm{Li}_{i}$. After impalement of the motoneuron and a control period, $\mathrm{LiCl}$ ( $5 \mathrm{mmol} \cdot \mathrm{1}^{-1}$, exchanged for $\mathrm{NaCl}$ ) was continuously perfused through the bathing chamber, resulting in an increase of $\mathrm{Li}_{i}$. At the same time, the membrane potential $\left(E_{m}\right)$ remained stable (the antidromic action potential was blocked, not illustrated). After about $120 \mathrm{~min}$, the recording became unstable and the electrode was withdrawn from the cell and placed into the bathing solution, which still was a Ringer solution with $5 \mathrm{mmol} \cdot 1^{-1} \mathrm{LiCl}$. At the arrow $(w)$ the $\mathrm{LiCl}$ solution was exchanged for normal Ringer. Then the ISME was calibrated using concentrations of 0 , 1,3 and $5 \mathrm{mmol} \cdot 1^{-1} \mathrm{LiCl}$ in solutions containing $100 \mathrm{mmol} \cdot 1^{-1} \mathrm{KCl}$ and $16 \mathrm{mmol} \cdot 1^{-1} \mathrm{NaCl}(a)$ and $100 \mathrm{mmol} \cdot 1^{-1} \mathrm{KCl}$ and $8 \mathrm{mmol} \cdot 1^{-1} \mathrm{NaCl}(b)$. The intracellular $\mathrm{Li}^{+}$concentration after $120 \mathrm{~min}$ was calculated as $3.6 \mathrm{mmol} \cdot 1^{-1}$. For this calculation the calibration $b$ was used because the baseline was identical to the intracellular level. Potentials in the $E_{m}$-trace during the calibration procedure are junction potentials at the bath ground $(\mathrm{Ag} / \mathrm{AgCl})$

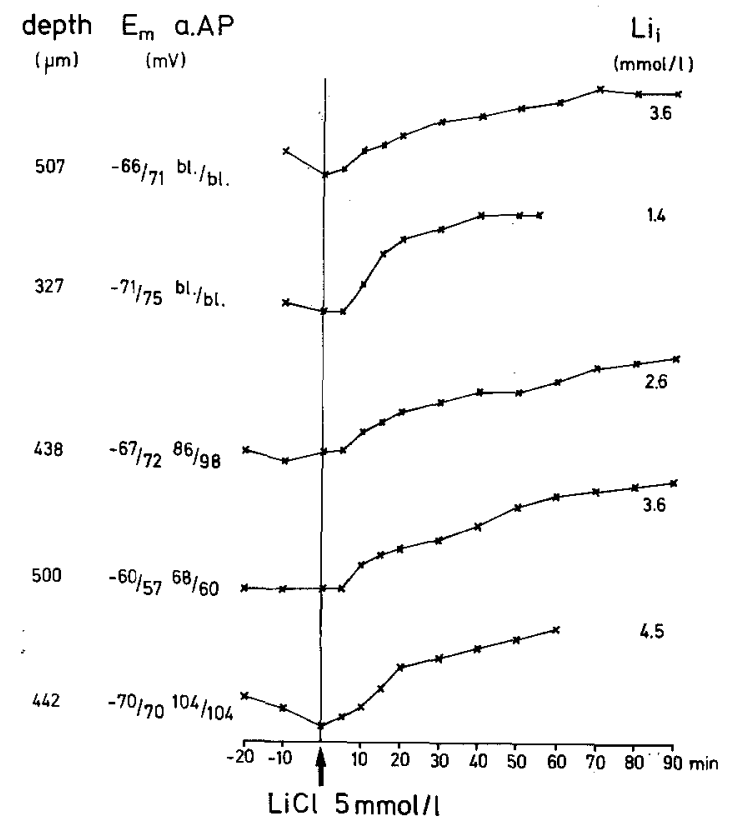

Fig. 6. Intracellular $\mathrm{Li}^{+}$levels after long lasting $\mathrm{Li}^{+}$applications. Summary of 5 motoneurons from experiments in which $\mathrm{Li}_{i}$ was observed for application times of $60-90 \mathrm{~min}$. On the left side the depth of the motoneuron, the resting membrane potential $\left(E_{m}\right)$ and height of the antidromically evoked action potential $(a . A P: b l .=$ antidromic invasion blocked) at the beginning and end of each recording are given. The traces illustrate the kinetics of the intracellular $\mathrm{Li}^{+}$levels redrawn from the original data. The values at the end of the traces give the intracellular $\mathrm{Li}^{+}$ levels at the end of the measurement. The continuous application of $5 \mathrm{mmol} \cdot 1^{-1} \mathrm{LiCl}$, either added to the Ringer solution ( 3 cells) or exchanged for $\mathrm{NaCl}$ ( 2 cells), was started at the vertical line

\section{Steady State Measurements}

Our longest intracellular recording is illustrated in Fig. 5 and shows that even after an application time of $120 \mathrm{~min} \mathrm{Li}_{i}$ did not reach a steady state. The ratio between $\mathrm{Li}_{i}$ and $\mathrm{Li}_{e}$ at this time was 0.7 . Observations on 5 different motoneurons, recorded for 60-90 min, are summarized in Fig. 6. In 2 of these examples a stable intracellular $\mathrm{Li}^{+}$level could be observed, whereas in the remaining neurons $\mathrm{Li}_{i}$ was still increasing after $90 \mathrm{~min}$ superfusion. However, in all cells studied so far, $\mathrm{Li}_{i}$ did not exceed the extracellular $\mathrm{Li}^{+}$ concentration. Our measurements also showed that $\mathrm{Li}^{+}$ $\left(5 \mathrm{mmol} \cdot 1^{-1}\right)$ did not alter $E_{m}$ and a. AP. Summarizing our longest intracellular recordings, $E_{m}$ was $-67.0 \pm 3.8 \mathrm{mV}$ (mean $\pm \mathrm{SD}, n=7$ ) before and $-68.3 \pm 5.8 \mathrm{mV}(n=7)$ after superfusion of $5 \mathrm{mmol} \cdot 1^{-1} \mathrm{Li}^{+}$for $30-120 \mathrm{~min}$. The corresponding data for the a. AP are $84.0 \pm 15.2 \mathrm{mV}(n=4)$ before and $85.0 \pm 20.0 \mathrm{mV}(n=4)$ after $\mathrm{Li}^{+}$superfusion. In the remaining 3 motoneurons the a. AP was blocked.

\section{Discussion}

We have used $\mathrm{Li}^{+}$-ISMEs (Güggi et al. 1975; Thomas et al. 1975)in order to determine the kinetics and the steady state intracellular $\mathrm{Li}^{+}$concentration in frog motoneurons. Results based on this method are reliable, with respect to the $\mathrm{Li}^{+}$ kinetics, since the response time of the electrodes is much faster than the $\mathrm{Li}^{+}$kinetics. On the other hand, the validity of the quantitative analysis is limited due to the partial sensitivity of the $\mathrm{Li}^{+}$exchanger to other interferring ions. In particular, $\mathrm{Na}^{+}$and $\mathrm{Ca}^{2+}$ (Güggi et al. 1975) have to be taken into account for (a) the composition of the intracellular calibration solution and (b) possible changes of the intracellular activities of these ions during the action of $\mathrm{Li}^{+}$. Our intracellular calibration solutions contained $100 \mathrm{mmol} \cdot 1^{-1} \mathrm{KCl}$ and 16 or $8 \mathrm{mmol} \cdot 1^{-1} \mathrm{NaCl}$. The concentration of $\mathrm{K}^{+}$-ions is based on data obtained with $\mathrm{K}^{+}$ISMEs in frog motoneurons (Sonnhof and Bührle 1981) for the membrane potential range of -60 to $-75 \mathrm{mV}$, to which our analysis was restricted. The concentration of $\mathrm{Na}^{+}$-ions has been chosen by comparing the voltage jump of the difference signal $\left(\mathrm{Li}_{i}\right)$ during withdrawal after an impalement and the change from the Ringer to the intracellular calibration solutions (see Fig. 5). However, the unknown composition of the intracellular fluid remains a source of error.

A second problem is a possible change in the activity of intracellular $\mathrm{Ca}^{2+}$ - and /or $\mathrm{Na}^{+}$-ions during the action of lithium. Aldenhoff and Lux (1980) reported that application of $1-40 \mathrm{mmol} \cdot 1^{-1} \mathrm{LiCl}$ resulted in a concentration - 
independent elevation of intracellular $\mathrm{Ca}^{\dot{ }+}$ by $100 \mathrm{nmol} \cdot 1^{-1}$ in snail neurons. Such an increase would not result in a measurable potential change with the $\mathrm{Li}^{+}$-ISMEs we used. On the other hand, as described in the results, we frequently observed voltage shifts of the $\mathrm{Li}^{+}$-ISME during changes in the membrane potential and/or the amplitude of the antidromic action potential. This may result from changes in intracellular $\mathrm{Na}^{+}$-concentration. Therefore, our analysis was restricted to motoneurons which had stable membrane potentials and constant action potential amplitudes. $\mathrm{Li}^{+}$itself $\left(5 \mathrm{mmol} \cdot 1^{-1}\right)$ seemed not to alter these parameters. In spite of possible small errors due to the factors discussed above, our data obtained from motoneurons of the isolated frog spinal cord are comparable with the transmembrane distribution of $\mathrm{Li}^{+}$in snail neurons (Thomas et al. 1975) and cultured neurons and glial cells (Janka et al. 1980a, b) showing a nonpassive distribution of $\mathrm{Li}^{+}$with an intra- to extracellular ratio of $<1$. If $\mathrm{Li}^{+}$is passively distributed, the ratio should be much higher, closer to the $\mathrm{K}^{+}$distribution ratio. An analysis of $\mathrm{Li}^{+}$levels in monkey and human brain after chronic, therapeutic, oral dosage also revealed a ratio close to 1 (Spirtes 1976). In contrast, in cultured glioma cells an intra-/ extracellular $\mathrm{Li}^{+}$ratio of up to 5.6 was observed (Gorkin and Richelson 1979). The non-passive distribution of $\mathrm{Li}^{+}$does not necessarily imply an active outward transport of $\mathrm{Li}^{+}$by the $\mathrm{Na}^{+} / \mathrm{K}^{+}$-pump (Ritchie and Straub 1980), since a $\mathrm{Na}^{+} / \mathrm{Li}^{+}$exchange system has been shown to maintain a low intracellular $\mathrm{Li}^{+}$concentration in red blood cells (Duhm et al. 1976; Ehrlich and Diamond 1980; Tosteson 1981) and possibly also in cultured neurons (Janka et al. 1980c).

The time course of the $\mathrm{Li}^{+}$movement into the frog spinal motoneurons is similar to the observations in snail neurons (Thomas et al. 1975) and cultured neurons (Richelson 1977; Janka et al. $1980 \mathrm{a}$, b) showing that considerable amounts of $\mathrm{Li}^{+}$are measurable intracellularly within a few minutes. This may indicate that the $\mathrm{Li}^{+}$induced impairment of stimulus induced electrogenic $\mathrm{Na}^{+} / \mathrm{K}^{+}$-transport observed in experiments involving application of $\mathrm{Li}^{+}$via the superfusion fluid might involve an interaction of $\mathrm{Li}^{+}$at the intracellular binding site of a mechanism, which is normally engaged in the $\mathrm{Na}^{+} / \mathrm{K}^{+}$-transport.

Acknowledgements. We are grateful to Prof. Simon, ETH Zürich, for the gift of Li-exchanger and to him and Dr. Ammann, ETH Zürich, for most valuable discussions throughout this project. We like to thank Miss C. Koestler for participation in several experiments and Dr. M. Galvan and Prof. J. Duhm for reading the manuscript and stimulating discussions. Expert technical and secretarial assistance was given by Mrs. C. Müller and Mrs. S. Syguda, respectively. The work was supported by grants $\mathrm{Br} 242 / 15$ and 17-2 given by the Deutsche Forschungsgemeinschaft.

\section{References}

Aldenhoff JB, Lux HD (1980) Measurement of steady state and transient changes of intracellular calcium in snail neurons under Lithiumchloride. Pflügers Arch (Suppl) 384:R19

Bruggencate G ten, Ullrich A, Galvan M, Förstl H, Baierl P (1981) Effects of Lithium application upon extracellular potassium in structures of the peripheral and central nervous system of rats. In: Lübbers DW, Acker H, Buck RP, Eisenman G, Kessler M, Simon W (eds) Progress in enzyme and ion-selective electrodes. Springer, Berlin Heidelberg New York, pp 135-140

Courtice CJ (1977) A circuit for recording evoked action potential amplitudes. J Physiol 268:1P
Davidoff RA, Hackman JC (1980) Hyperpolarization of frog primary afferent fibres caused by activation of a sodium pump. J Physiol 302:297-309

Duhm J, Eisenried F, Becker BF, Greil W (1976) Studies on the lithium transport across the red cell membrane $\mathrm{I} . \mathrm{Li}^{+}$uphill transport by the $\mathrm{Na}^{+}$-dependent $\mathrm{Li}^{+}$countertransport system of human erythrocytes. Pflügers Arch 364:147-155

Ehrlich BE, Diamond JM (1980) Lithium, membranes, and manicdepressive illness. J Membr Biol 52:187-200

Gorkin RA, Richelson E (1979) Lithium ion accumulation by cultured glioma cells. Brain Res 171:365-368

Grafe P, Rimpel J, Koestler C, Bruggencate G ten (1981) Actions of lithium on motoneurons and extracellular potassium concentration in the isolated frog spinal cord. Pflügers Arch (Suppl) 389:R28

Güggi M, Fiedler U, Pretsch E, Simon W (1975) A lithium ion-selective electrode based on a neutral carrier. Anal Lett 8:857-866

Janka Z, Szentistvanyi I, Juhasz A, Rimanoczy A (1980a) Steady-state distribution of lithium during cultivation of dissociated brain cells. Experientia 36:1071-1072

Janka Z, Szentistvanyi J, Juhasz A, Rimanoczy A (1980b) Difference in lithium transport between neurones and glia in primary culture. Neuropharmacology 19:827-830

Janka Z, Szentistvanyi I, Rimanoczy R (1980c) The influence of external sodium and potassium on lithium uptake by primary brain cell cultures at "therapeutic" lithium concentration. Psychopharmacology $71: 159-165$

Ploeger EJ (1974) The effects of lithium on excitable cell membranes. On the mechanism of inhibition of the sodium pump of non myelinated nerve fibres of the rat. Eur J Pharmacol 25:316-321

Richelson E (1977) Lithium ion entry through the sodium channel of cultured mouse neuroblastoma cells: a biochemical study. Science 196:1001-1002

Ritchie JM, Straub RW (1957) The hyperpolarization which follows activity in mammalian non-medullated fibres. J Physiol 136:80-97

Ritchie JM, Straub RW (1980) Observations on the mechanism for the active extrusion of lithium in mammalian non myelinated nerve fibres. J Physiol 304:123-134

Smith ICH (1979) The electrogenic potential in rat nerve fibres: some effects of lithium and thallium. J Physiol 294:135-144

Sonnhof U, Grafe P, Krumnikl J, Linder M, Schindler L (1975) Inhibitory postsynaptic actions of taurine, GABA and other amino acids on motoneurons of the isolated frog spinal cord. Brain Res $100: 327-341$

Sonnhof U, Richter DW, Taugner R (1977) Electrotonic coupling between frog spinal motoneurons. An electrophysiological and morphological study, Brain Res 138:197-215

Sonnhof U, Bührle Ch (1981) An analysis of glutamate-induced ion fluxes across the membrane of spinal motoneurons of the frog. In: DiChiara G, Gessa GL (eds) Glutamate as a neurotransmitter. Raven Press, New York, pp 195-204

Spirtes MA (1976) Lithium levels in monkey and human brain after chronic, therapeutic, oral dosage. Pharmacol Biochem Behav $5: 143-147$

Tang CM, Cohen MW, Orkand RK (1980) Electrogenic pumps in axons and neuroglia and extracellular potassium homeostasis. Brain Res 194:283-286

Thomas RC (1978) Ion-sensitive intracellular microelectrodes. Academic Press, London, New York

Thomas RC, Simon W, Oehme M (1975) Lithium accumulation by snail neurones measured by a new $\mathrm{Li}^{+}$sensitive microelectrode. Nature 258:754-756

Tosteson DC (1981) Cation countertransport and cotransport in human red cells. Fed Proc 40:1429-1433

Ullrich A, Baierl P, Bruggencate G ten (1980) Extracellular potassium in rat cerebellar cortex during acute and chronic lithium application. Brain Res 192:287-290

Received July 25, 1981/Accepted March 3, 1982 